\begin{tabular}{|c|c|c|}
\hline & JHE 5 (2) (2020) 86-93 & \\
\hline & Journal of Health Education & \\
\hline $\begin{array}{l}\text { Journal of } \\
\text { HealthEducation }\end{array}$ & http://journal.unnes.ac.id/sju/index.php/jhealthedu & $=$ \\
\hline
\end{tabular}

\title{
Role of Public Health Center Staffs in Socialization, Education and Campaign to Increase Exclusive Breastfeeding Coverage
}

\author{
Rezyana Budi Syahputri ${ }^{1 \bowtie}$, Dzul Akmal $^{2}$ \\ DOI: http://dx.doi.org/10.15294/jhe.v5i2.36063 \\ ${ }^{1}$ Universitas Sebelas Maret, Indonesia \\ ${ }^{2}$ STIKES Jenderal Achmad Yani Cimahi, Indonesia
}

\section{History Article}

Submitted 11 November 2019 Revised 12 June 2020

Accepted 23 September 2020

\section{Keywords}

campaign; exclusive

breastfeeding; education; staff's role; socialization

\begin{abstract}
Background: The achievement of breastfeeding in Surakarta City in 2017 was $76.7 \%$ while the target of infants with exclusive breastfeeding is $80 \%$. The lowest achievement of exclusive breastfeeding was at Gilingan Public Health Center $(66.1 \%)$. The role of health center staff is very important in improving and supporting social breastfeeding efforts.

Method: The study was descriptive qualitative research using a case study approach. The informant of this research consists of 2 main informants and 3 triangulation informants with a purposive sampling technique.

Results: The role of health center staff in socialization were in the form of counseling and individual counseling; education program were in the form of class for pregnant women and class for parents with under-five children. There has been no health campaign implementation in the World Breastfeeding Week celebration.

Conclusion: The socialization and education program could be implemented but for the campaign has not been implemented. It was because of a lack of coordination by Gilingan Public Health Center's staff.
\end{abstract}

\section{How to Cite}

Syahputri, R. B., \& Akmal, D. (2020). Role of Public Health Center Staffs in Socialization, Education and Campaign to Increase Exclusive Breastfeeding Coverage. JHE (Journal of Health Education), 5(2), 86-93.
${ }^{\square}$ Corresponding Author: J1. Ir. Sutami No. 36 A, Surakarta

E-mail: rezyanabs@gmail.com
p-ISSN 2527-4252

e-ISSN 2528-2905 
Rezyana Budi Syahputri \& Dzul Akmal / Journal of Health Education 5 (2) (2020) 86-93

\section{INTRODUCTION}

Exclusive breastfeeding is a strategic investment in improving the quality of human resources. The strategic value of exclusive breastfeeding has stimulated world awareness to create an event in the form of World Breastfeeding. Through this global breastfeeding week, it hoped that the whole world will provide support for mothers, as heroes for children, families and society, and provide the best for their children to continue optimize children's growth and development. Every 1-6 August is celebrated as the day of World Breastfeeding which is held for one week to remind the public how important breastfeeding is for the development of babies. Currently there were more than 170 countries that have organized world breastfeeding week with various activities, including in Indonesia (Kepmenkes No. 450 Th. 2004 Tentang Pemberian ASI, 2020).

Exclusive breastfeeding can reduce 13\% of child mortality. About $50-60 \%$ of child deaths under 5 years caused by malnutrition and sub-optimal breastfeeding. However, unfortunately the achievement of exclusive breastfeeding in Indonesia has not reached the expected number, it was $42 \%$ (Kementrian Kesehatan Republik Indonesia, 2016). Scope of exclusive breastfeeding in the province of Central Java also not optimal, which amounted to $61.60 \%$. In line with the scope of exclusive breastfeeding at the provincial level, the realization of exclusive breastfeeding in Surakarta also low at occupying 10th rank lowest in Central Java with a coverage of $52.43 \%$ (Dinas Kesehatan Provinsi Jawa Tengah, 2017).

The achievement of exclusive breastfeeding in the Surakarta city was still far from the national target. Nationally, the target of baby that exclusively breastfed from the Ministry of Health is $80 \%$, while the achievement in Surakarta in 2017 was $76.7 \%$. Of all Public Health Center in Surakarta, the lowest coverage of exclusive breastfeeding was at Gilingan Health Center, which is only $66.1 \%$ (Dinas Kesehatan Surakarta, 2016).

Several previous studies examined the factors causing the inadequacy of exclusive breastfeeding coverage. There were four determinants of exclusive breastfeeding coverage, namely knowledge of exclusive breastfeeding, family support, myths/beliefs and promotion of formula milk. These four factors influence each other in the success of exclusive breastfeeding (Widdefrita \& Mohanis, 2013). Mothers also need support from the people around them to support the success of exclusive breastfeeding behavior, both from family and from health officers or those who help with childbirth (Waits et al., 2018). The role of health officers was very important in protecting, enhancing, and supporting breastfeeding efforts must be seen in terms of their broad involvement in social aspects (Khanal et al., 2015).

Several studies also shown that health promotion activities of health workers play a very important role in achieving the target of exclusive breastfeeding (Little et al., 2019; Pemo et al., 2020). The role of officers in health promotion was very much needed in relation to Community Based Health Efforts/Upaya Kesehatan Berbasis Masyarakat (UKBM) in the form of preventive and promotive measures to be realized in accordance with the Decree of the Minister of Health Number 1114/Menkes/SK/VII/2005 concerning regional health promotion guidelines.

A preliminary study at the Gilingan Public Health Center in Surakarta City showed that there are health center officers who have a special task to increase the coverage of exclusive breastfeeding. But unfortunately there were problems regarding the realization of socialization programs, education and campaigns on exclusive breastfeeding. The ineffective implementation of health promotion programs was one of the factors affecting the coverage of exclusive breastfeeding at Gilingan Health Center.

Therefore, it was necessary to conduct a study to analyze the role of health care center officers in socialization, education, and campaigns to increase exclusive breastfeeding coverage in the working area of the Gilingan Public Health Center.

\section{METHODS}

This type of research was qualitative research that produces descriptive data in the form of words with in-depth interviews. This study used a case study approach, in which the case in the study was the role of Public Health Center officers to increase the coverage of exclusive breastfeeding. The researcher also acts as a human instrument to determine the focus of the research, selecting research informants as the data source, interpreting the data and concluding existing findings. The focus of this research was the role of Public Health Center officers in socialization, education and campaigns to increase exclusive breastfeeding coverage.

The research conducted on 27-28 December 2017 in the working area of the Gilingan Public Health Center. The main informants in 
this study were two people, namely an officer of the Gilingan Public Health Center who occupies the field of health promotion and a nutritionist. While the triangulation informants totaled three people, namely a breastfeeding motivator and two breastfeeding mothers who used health services at the Gilingan Public Health Center. The sampling technique used in this study was purposive sampling. How to collect data using semi-structured interviews and observations. Processing and analysis of data is done by means of coding, data reduction, data presentation, conclusion and verification.

\section{RESULTS AND DISCUSSIONS}

In this study, researchers interviewed 2 main informants at the Gilingan Public Health Center and 3 triangulation informants who were in the working area of the Gilingan Public Health Center. The Table $1 \& 2$ of the characteristics of research informants after conducting interviews.

Table 1. Characteristic of Key Informants

\begin{tabular}{|c|c|c|c|c|}
\hline $\begin{array}{l}\text { Infor- } \\
\text { mant }\end{array}$ & Age & Sex & Profession & $\begin{array}{l}\text { Length } \\
\text { of Work }\end{array}$ \\
\hline IU 1 & 43 & Female & Nutritionists & 13 years \\
\hline IU 2 & 33 & Female & $\begin{array}{l}\text { Health Pro- } \\
\text { motor }\end{array}$ & 7 years \\
\hline
\end{tabular}

Table 2. Characteristic of Triangulation Informants

\begin{tabular}{lll}
\hline Informant & Age & Profession \\
\hline IT 1 & 27 & Housewife \\
IT 2 & 34 & Housewife \\
IT 3 & 49 & Housewife \\
\hline
\end{tabular}

The role of Public Health Center officers can determine health development towards a healthy Indonesia. According to (Maulana, 2017), the various roles of Public Health Center officers ranging from customers, counselors, motivators, facilitators and communicators should be carried out at the Gilingan Public Health Center. Public Health Center should lead to Public Health Efforts/Upaya Kesehatan Masyarakat (UKM) that focus on preventive and promotive (Kim et al., 2018). This is still a problem in the scope of the Public Health Center. Gilingan Public Health Center officers do not play a role in health promotion so that the coverage of exclusive breastfeeding is the lowest in Surakarta.

Research by Ihudiebube-Splendor et al (2019) states that if in an area that have low kno- wledge about exclusive breastfeeding and lack of intention. Health officers can train the population to be able to increase their intention by combining facility-based and methods, such as breastfeeding counseling, education, and in-house support especially for pregnant and expectant mothers.

\section{Socialization of the Exclusive Breastfeeding Program}

Health officer is someone who is respected, respected in the eyes of the client because has a high status in accordance with his education. Its role is needed so that health officers must be able to provide conditions that can influence clients to be able to behave positively towards health (UCL Institute of Health Equity, 2013). Social support from health officers can be seen when implementing health services, namely by explaining, inviting, giving sympathy and providing examples for healthy behavior (Widdefrita \& Mohanis, 2013).

The role of health officers in supporting exclusive breastfeeding was very important. In fact, the lack of midwives, coupled with a lack of developmental professionals on breastfeeding promotion and support, is an additional barrier to the promotion of exclusive breastfeeding (Little et al., 2019; Pemo et al., 2020). Socialization in the form of counseling can be the first step for health workers to support exclusive breastfeeding. According to Nuzhat et al., (2019) the importance of strong counseling on the practice of breastfeeding can help rebuild lactation, especially infants who are acutely ill.

Researchers asked questions to informants about what socialization programs had been implemented by the Gilingan Public Health Center. IU 1 answered,, "... counseling, promotion, the formation of breastfeeding motivators and mother's KP ..." ("...konseling, penyuluhan, pembentukan motivator ASI dan KP Ibu...'). Meanwhile, IU 2 answered, "... counseling on exclusive breastfeeding and Vitamin A, Mother's KP, there is individual counseling too ..." ("...penyuluhan tentang ASI eksklusif dan Vitamin A, KP Ibu, ada konseling individu juga...'). The answers to IT 1 and 3 regarding the outreach program are as follows: "... more to the counseling yourself, sis, usually at the posyandu (integrated health post), miss ..." ("...lebih ke konseling sendiri gitu mbak, biasane ya di posyandu itu mbak...") and the answer to IT 2 "... verbal sometimes yes on the screen, a photocopy is given. .. " " "..lisan aja kadang ya di layar, dikasih fotocopyan...").

Based on the interview, the form of providing information for the Gilingan Public Health Center officers was individual counseling and 
several times with the form of counseling which was also distributed with the counseling materials carried out at the integrated health post and the existence of the Mother Support Group / Kelompok Pendukung Ibu (KP Ibu).

Gilingan Public Health Center's officers have tried to improve the health of babies by influencing the behavior of mothers on exclusive breastfeeding. The socialization program on exclusive breastfeeding that has been implemented by the Gilingan Public Health Center was counseling and individual counseling. Exclusive breastfeeding counseling was carried out at the integrated health post according to the schedule of visits by Public Health Center officers, while individual counseling is carried out at the integrated health post, client's house and Public Health Center.

Individual counseling regarding infant nutrition was needed because it affects the knowledge and attitudes of breastfeeding mothers (Waits et al., 2018). Research by Masthalina \& Agustina (2018) stated that there were significant differences before and after nutritional counseling interventions were given to breastfeeding mothers $(p=0.000)$. Counseling was carried out on an incentive and scheduled basis, then breastfeeding mothers practice independently. Raissian \& Su, (2018) stated in his research that mother who intend to breast-feed have a knowledge more about breastfeeding and like to seek for sources of information about nutrition and diet than women who did not intend to breastfeed so one counseling intervention is required to improve the mother's intention to breastfeed.

This breastfeeding counseling was an effective public health intervention to increase coverage of exclusive breastfeeding. Interventions should be done face-to-face, but can also be provided by telephone. This counseling was carried out starting from antenatal and postnatal, because information about exclusive breastfeeding needed since pregnant women are able to prepare for breastfeeding needs and can provide a full 6 months (McFadden et al., 2019; Susiloretni et al., 2019).

Public Health Center officers provide encouragement in providing exclusive breastfeeding by protecting and enhancing the behavior of mothers who breastfeed exclusively or to breastfeed their babies for up to 2 years. Public Health Center officers also help mothers solve barriers and problems about breastfeeding such as not smooth breastfeeding, stress control and management of expressed breast milk by giving approaches to problem mothers and encouraging breastfeeding by fostering mother's trust.

The next question raised regarding the evaluation of the implementation of exclusive breastfeeding information. According to IU 1 “... our evaluation is mostly the motivator, if we only meet the mother at the integrated health post ..." ("...evaluasi kita paling ke motivatornya, kalau sama ibunya paling ketemu kalau di posyandu aja...") and IU 2 answered "... every month we will have an evaluation, from the results of data collection, we will evaluate the counseling. at the UKM meeting ..." ( “...tiap bulan itu nanti kita ada evaluasi, dari hasil pendataan, nanti kita evaluasi penyuluhan di pertemuan UKM...").

The results of the interview stated that the evaluation was carried out with breastfeeding motivators and the UKM meeting was based on the results of data collection on breastfeeding coverage conducted by the cadres.

However, there were obstacles in the application of this method, such as the absence of mothers during counseling and the number of mothers who do not apply exclusive breastfeeding due to stress so that the milk is not smooth and the mother works so that the baby is given formula milk.

Evaluation needed so that officers know the impact of each program implemented. Breastfeeding counseling, exclusive breastfeeding counseling is needed because it has an effect on the duration of breastfeeding (Pemo et al., 2020). Breastfeeding mothers needed intensive information and positive exposure so that the mindset about exclusive breastfeeding can be well formed (Kannaiah, 2019).

The socialization program by the Gilingan Public Health Center's officer is quite good because the socialization program has been implemented but has not been optimal, such as there was no definite schedule because it is only based on integrated health post visits, individual counseling carried out at the client's home is only carried out by breastfeeding motivators in each RW even though breastfeeding mothers need more attention of Public Health Center officers.

\section{Education in Exclusive Breastfeeding Program}

The education program that has been implemented by the Gilingan Public Health Center was in the form of pregnant women classes, toddler classes and breastfeeding motivator training. The target of the educational program in increasing the coverage of exclusive breastfeeding was pregnant women and lactating women. The role of the Gilingan Public Health Center officers in education was as counselors, facilitators, moti- 
Rezyana Budi Syahputri \& Dzul Akmal / Journal of Health Education 5 (2) (2020) 86-93

vators and communicators. In the education program, responsible officers are nutritionists, health promotion officers and midwives (Pemo et al., 2020; Zhang et al., 2018).

An understanding of the knowledge of breastfeeding as a staple in the exposure of health communities (Little et al., 2019). The duration of breastfeeding itself can be achieved through programs that improve the process of breastfeeding behavior, such as the presence of pregnancy classes (Susiloretni et al., 2019).

This evidenced from the results of interviews with researchers regarding the forms of education and training given to pregnant and lactating mothers. IU 1 answered "... train breastfeeding motivators, make targets, classes for pregnant women and toddlers ..." ("...melatih motivator ASI, buat sasarannya, kelas ibu hamil dan balita...") and IU 1 stated "... there is a class for pregnant women, a class for toddlers exists and the formation of motivators is there ..." ("...kelas ibu hamil ada, kelas balita ada dan pembentukan motivator ada..."). This is supported by a statement from IT 1 "... how about you? Oh yes there is ... Pregnancy class to? Good, given various materials starting from pregnancy, childbirth and breastfeeding ("...kaya gimana mbak? Oo iya ada... Kelas hamil itu to? Bagus, diberikan materi macam-macam mulai masa hamil, melahirkan dan menyusui").

Pregnant women class can grow the mother's intention to provide exclusive breastfeeding. The intention to provide exclusive breastfeeding needed to be strengthened by a delivery service policy by implementing exclusive breastfeeding at every birth, and supported by every midwife at the Public Health Center (Ismiati et al., 2019).

Researchers also ask questions about the material and media used in educational programs. IU 1 stated "... the material is in accordance with the module for pregnancy and toddler classes or KIA. But for the training from the resource person, what is clear is that exclusive breastfeeding is included in the material ..." ("... materinya sesuai modul kelas hamil dan balita atau KIA. Tapi untuk pelatihan dari narasumber, yang jelas ASI eksklusif masuk materinya..."). IU 2 added, "... leaflets, flipcharts, manuals or modules, puppets, $\mathrm{mmm}$ artificial breasts, if we need a video, we'll give a video ..." ( "...leaflet, lembar balik, buku panduan atau modul, peraga ya boneka, mmm tiruan payudara, kalo butuh video ya kita berikan video...").

The response of mothers who take part in educational programs such as pregnancy classes, toddler classes and breastfeeding motivator training also good. The following is the answer of IT 1 "... using a tancep screen, miss, with direct practice
... good sis, everyone is entertained, it will be easy ..." ("...menggunakan layar tancep gitu mbak, sama praktik langsung...bagus mbak, semua terhibur jadinya ya mudeng...") and IT 2 added "... yo nice sis, everything is compact, it's clear so that the given material (obviously the time to deliver the material) ... " ("...yo apik mbak, semuanya kompak, jelas ngono nek memberi materi (jelas waktu penyampaian materi)...")

The educational program that has been implemented by the Gilingan Public Health Center has a weakness, namely the absence of an indicator of program success. The instrument to assess the success rate of the program was only carried out in the toddler class after 6 months (one period) was completed. The instrument filled by companion cadres who follow the toddler class. The instrument is related to the delivery of the material, the material raised, the media used and the pretest and post-test of the material presented during one period. This instrument is an evaluation tool for Gilingan Public Health Center officers about the programs that have been implemented.

Researchers gave the question of the role of health centers in providing education officer linked exclusively breastfed in the form of education and training has been maxima 1 . According to IU 1 " $\ldots$ it is adjusted to the counselor and facilitator but I think so ..." ("...disesuaikan dengan konselor dan failitator tapi ya saya rasa sudah..."). Meanwhile, IU 2 answered in contrast "... yes, we still have to keep improving, right? So far, the coverage is still lacking, right ..." ("...ya kita tetep harus memperbaiki terus sih, kan selama ini cakupannya juga masih kurang kan...").

According to Gavine et al (2017) there was not much evidence that education and training for pregnant and breastfeeding mothers can increase the achievement of exclusive breastfeeding. This study supports that education and training conducted by health workers can make mothers breastfeed as early as possible (implementing breastfeeding early initiation (IMD) as the first step in exclusive breastfeeding).

The researcher also asked about the media used in education and training. According to IU 2, “... the most interesting media were IMD videos and breast massage, maybe other materials could follow these media and methods ..." ("...media yang paling menarik yang waktu video IMD dan breast massage, mungkin materi yang lain bisa mengikuti media dan metode tersebut..."). IU 1 added her complaint regarding the existing media, "... maybe just reproduce it, the number is minimal. So it is used interchangeably at the time of practice ... ", ("...mungkin lebih diperbanyak aja, 
memang minim jumlahnya. Jadi digunakan bergantian pada saat praktiknya...")

The media played an important role in increasing the knowledge and positive attitudes of mothers regarding exclusive breastfeeding (Permatasari et al., 2018). Health education using audio-visual media was more effective in increasing the knowledge and attitudes of breastfeeding mothers. Mother pays attention by using two senses at once, the senses of hearing and sight. These senses function very effectively in digesting the messages conveyed (Wijayanti, 2019).

Based on analysis of interviews, it needed for increased monitoring of the mothers who breastfeed by breastfeeding motivator. This related to the low coverage of exclusive breastfeeding in the working area of the Gilingan Public Health Center. Monitoring breastfeeding mothers accompanied by health center officers is planned so that exclusive breastfeeding coverage can increase next year.

\section{Exclusive Breastfeeding Program Campaign}

Communication of social and behavioral changes can have a major impact on behaviors related to child survival and optimal nutritional status (Fox \& Obrego, 2014). The approach that often taken was interpersonal communication and some have a mass media component. The advantages of using mass media include reach and frequency, control over message content and delivery, consistency, and relatively low costs per person exposed (Nguyen et al., 2017).

Campaign according to Kotler (2013) mean a form of communication action that can cover the entire process and phenomena of campaign practices that occur in the field. The campaign has clear characteristics, among others; clear sources, there were those who are initiators, designers, transmitters and even those in charge of a campaign product (campaign makers), as well as any individual receiving the campaign message can identify and evaluate the credibility of the source of the message at any time.

Campaigns can be implemented through social media by creating groups of breastfeeding mothers because social media groups can positively influence attitudes, knowledge and behavior and lead to longer breastfeeding duration (Skelton et al., 2018). Mass media campaigns led to greater changes in exclusive breastfeeding behavior. The campaign refers to the geographic location of the intervention to be carried out so that the mass media has influence through the social diffusion process (Naugle, 2016).

Researchers give questions about the form of exclusive breastfeeding campaigns that have been implemented. IU 1 replied, "... for the mass campaign rich in banners it has not been ..." ("... untuk kampanye massal kaya spanduk itu belum...") and IU 2 clearly stated, "... there is not yet ..." "... belum ada..."). This is reinforced from the answer to IT 1, "... Whoa, never miss, never know me sis, not yet ..." "...Waah, nggak pernah mbak, belum pernah tau saya mbak, belum ada...".

An exclusive breastfeeding campaign needed because it acts as a platform that provides information to a heterogeneous audience and more profitable because it also reaches prospective mothers (already pregnant or not). This campaign also has an impact on families and husbands who can access this information service (Chuckwu-Okoronkwo et al., 2019). Campaigns with general targets can also be carried out on social media, Marcon et al., (2018) stated that social media is used to network, promote, and further support breastfeeding widely in its large and diverse global online community .

Related to the role of health center officers in health campaigns to increase the coverage of exclusive breastfeeding . IU 1 answered, "... following representatives from the city level with a parade of breastfeeding counselors ..." ( "...mengikuti perwakilan dari tingkat kota dengan parade konselor ASI..."), while IU 2 answered, "... until now they are still nutrition officers, health promotion officers have not been involved ...", ("...sampai saat ini masih petugas gizi saja, petugas promkes belum dilibatkan...)" and IU 2 added "... if for example it is needed, it can be done by making MMT World Breastfeeding Week ..." ("...kalo misal dibutuhkan sih ya bisa dilakukan dengan pembuatan MMT Pekan ASI Sedunia...")

According to Basri, (2016) the message characteristic factors (message content and delivery) in a health campaign can change the target attitude in health habituation. This mean that the initiator of a campaign product must be expert in creating campaign messages with clear sources and in accordance with the desired target audience (Kim et al., 2018). This also related to campaign objectives that are always clear, specific and measurable (Kim et al., 2018)

Future exclusive breastfeeding promotion interventions should target four factors, namely breastfeeding knowledge, attitudes, subjective norms and practice control. Among these four factors, knowledge about breastfeeding was a factor that contributes to exclusive breastfeeding so that the main target was to increase the knowledge of prospective mothers so that good subjective attitudes and norms about breastfeeding will 
emerge (Zhang et al., 2018).

The role of Gilingan Public Health Center officers in the campaign has not been realized because planning and coordinators are held by nutrition officers as breastfeeding counselors at Gilingan Public Health Center, while health promotion officers have not been involved in planning health campaigns. Based on the results of the interview which stated that the officer in charge of planning and executing the health campaign was a nutrition counselor who, in fact, came from nutrition officers and midwives who were not in accordance with the field of knowledge they had lived.

The Gilingan Public Health Center can include health promotion officers in breastfeeding counselor training held by the Surakarta Health Office so that health promotion officers can make plans according to the characteristics of a health campaign that can attract audiences to change their behavior.

\section{CONCLUSION}

Based on the results of the study, it could be concluded that the public health center officers had just shown an active role in 2 programs, the socialization and education of the exclusive breastfeeding program. The exclusive breastfeeding program campaign has not been carried out completely.

To support the achievement of exclusive breastfeeding, then it was recommended to be in the planning program of exclusive breastfeeding campaign involved not only the nutritional officer, but it need to be involvement in the field of health promotion and across other sectors.

\section{REFERENCES}

Basri, H. (2016). Pengaruh Karakteristik Pesan Kampanye Kesehatan Terhadap Sikap Hidup Sehat Ibu Ibu Anggota Posyandudi Kota Bandar Lampung. Jurnal Bisnis Darmajaya, 2(1), 102103.

Chuckwu-Okoronkwo, S. O., Uzoma, C. O., \& Innocent, I. (2019). Impact Assesment of Exclusive Breastfeeding Media Campaign Among Mothers in Selected Metropolitasn Cities in South East Nigeria 1. Research on Humanities and Social Sciences, 9(14), 8-18.

Dinas Kesehatan Provinsi Jawa Tengah. (2017). Profil Kesehatan Provinsi Jawa Tengah 2017 (3511351(24).

Dinas Kesehatan Surakarta. (2016). Profil Kesehatan Kota Surakarta.

Fox, E., \& Obregón, R. (2014). Population-level behav- ior change to enhance child survival and development in low-and middle-income countries. Journal of Health Communication, 19(sup1), 3-9.

Gavine, A., MacGillivray, S., Renfrew, M. J., Siebelt, L., Haggi, H., \& McFadden, A. (2017). Education and training of healthcare staff in the knowledge, attitudes and skills needed to work effectively with breastfeeding women: A systematic review. International Breastfeeding Journal, 12(1), 1-10.

Ihudiebube-Splendor, C. N., Okafor, C. B., Anarado, A. N., Jisieike-Onuigbo, N. N., Chinweuba, A. U., Nwaneri, A. C., Arinze, J. C., \& Chikeme, P. C. (2019). Exclusive Breastfeeding Knowledge, Intention to Practice and Predictors among Primiparous Women in Enugu SouthEast, Nigeria. Journal of Pregnancy, 2019.

Ismiati, I., Lubis, Y., \& Susmini, S. (2019). Participation in Pregnant Mother Class and Implementation of Exclusive Breastfeeding in Betungan Community Health Center, Bengkulu. Journal of Maternal and Child Health, 4(1), 30-39.

Kannaiah, B., \& M, R. (2019). Impact of Lactation Counseling To Mothers on Breast Feeding Practices. 6(2), 13-22.

Kementrian Kesehatan Republik Indonesia. (2016). Profil Kesehatan Indonesia 2016.

Kepmenkes No. 450 Th. 2004 Tentang Pemberian ASI, Pub. L. No. 450 Tahun 2004 (2020).

Khanal, V., Lee, A. H., Karkee, R., \& Binns, C. W. (2015). ostpartum Breastfeeding Promotion and Duration of Exclusive Breastfeeding in Western Nepal. Birth, 42(4), 329-336.

Kim, S. K., Park, S., Oh, J., Kim, J., \& Ahn, S. (2018). Interventions promoting exclusive breastfeeding up to six months after birth: A systematic review and meta-analysis of randomized controlled trials. International Journal of Nursing Studies, 80(January), 94-105.

Kotler, P. (2013). Marketing : Approach Planned Social Change. 35(3), 3-12.

Little, E. E., Polanco, M. A., Baldizon, S. R., Wagner, P., \& Shakya, H. (2019). Breastfeeding knowledge and health behavior among Mayan women in rural Guatemala. Social Science and Medicine, 242(September), 112565.

Marcon, A. R., Bieber, M., \& Azad, M. B. (2019). Protecting, promoting, and supporting breastfeeding on Instagram. Maternal \& child nutrition, 15(1), e12658.

Masthalina, H., \& Agustina, Z. (2018). Nutrition counseling toward knowledge and attitude of breastfeeding mothers and infant growth in Lubuk Pakam Subdistrict. Kesmas, 12(3), 127-133.

Maulana, M. N. (2017). Peran, Petugas Kesehatan, Partisipasi Ibu, Imunisasi Bayi. Jurnal Kesehatan Masyarakat, 3(1), 148-163.

McFadden, A., Siebelt, L., Marshall, J. L., Gavine, A., Girard, L. C., Symon, A., \& MacGillivray, S. (2019). Counselling interventions to enable women to initiate and continue breastfeeding: A systematic review and meta-analysis. Interna- 
tional Breastfeeding Journal, 14(1), 1-19.

Naugle, D. A. (2016). The evaluation of a mass media campaign to promote exclusive breastfeeding in Vietnam. ProQuest Dissertations and Theses, 180.

Nguyen, T. T., Alayón, S., Jimerson, A., Naugle, D., Nguyen, P. H., Hajeebhoy, N., Baker, J., Baume, C., \& Frongillo, E. A. (2017). The association of a large-scale television campaign with exclusive breastfeeding prevalence in Vietnam. American Journal of Public Health, 107(2), 312318.

Nuzhat, S., Islam, R., Ahmed, T., Sarker, S. A., Khan, A. I., Purkayastha, S., \& Chisti, M. J. (2019). Impact of Routine Counseling on Breastfeeding Status in Hospitalized Infants Below 6 Months: Observation From a Large Diarrheal Disease Hospital in Bangladesh. Global Pediatric Health, 6, $2333794 X 1985494$.

Pemo, K., Phillips, D., \& Hutchinson, A. M. (2020). Midwives' perceptions of barriers to exclusive breastfeeding in Bhutan: A qualitative study. Women and Birth, 33(4), e377-e384.

Permatasari, T. A. E., Sartika, R. A. D., Achadi, E. L., Purwono, U., Irawati, A., Ocviyanti, D., \& Martha, E. (2018). Exclusive breastfeeding intention among pregnant women. Kesmas, 12(3), 134-141.

Raissian, K. M., \& Su, J. H. (2018). The best of intentions: Prenatal breastfeeding intentions and infant health. SSM - Population Health, 5(May), 86-100.

Skelton, K. R., Evans, R., LaChenaye, J., Amsbary, J.,
Wingate, M., \& Talbott, L. (2018). Exploring social media group use among breastfeeding mothers: qualitative analysis. JMIR pediatrics and parenting, 1(2), e11344.

Susiloretni, K. A., Hadi, H., Blakstad, M. M., Smith, E. R., \& Shankar, A. H. (2019). Does exclusive breastfeeding relate to the longer duration of breastfeeding? A prospective cohort study. Midwifery, 69, 163-171.

UCL Institute of Health Equity. (2013). Working for Health Equity: The Role of Health Professionals. Policy Document, 88-90.

Waits, A., Guo, C. Y., \& Chien, L. Y. (2018). Evaluation of factors contributing to the decline in exclusive breastfeeding at 6 months postpartum: The 2011-2016 National Surveys in Taiwan. Birth, 45(2), 184-192.

Widdefrita, \& Mohanis. (2013). Peran Petugas Kesehatan Dan Status Pekerjaan Ibu Dengan Pemberian Asi Ekslusif. JKMA: (Jurnal Kesehatan Masyarakat Andalas) (Andalas Journal of Public Health), 8(1), 40-45.

Wijayanti, K. (2019). Audio Visual Media in Breast Feeding Health Education Related to Knowledge and Attitude of Lactation Women. International Journal of Science Basic and Applied Research (IJSBAR), 4531, 219-225.

Zhang, Z., Zhu, Y., Zhang, L., \& Wan, H. (2018). What factors influence exclusive breastfeeding based on the theory of planned behaviour. Midwifery, 62, 177-182. 